\title{
Manufacturing Deficiency
}

National Cancer Institute

\section{Source}

National Cancer Institute. Manufacturing Deficiency. NCI Thesaurus. Code C91881.

Problems traced to manufacturing process. 